\title{
Karyological Characteristics of Some Endemic Onobrychis Taxa Belonging to Onobrychis Section Naturally Grown in Turkey
}

\author{
Onur İleri*, Süleyman Avcı
}

Department of Field Crops, Faculty of Agriculture, Eskisehir Osmangazi University, 26040 Eskişehir, Turkey

\begin{tabular}{l}
\hline A R T I C L E I N F O \\
Research Article \\
Received 03 January 2018 \\
Accepted 27 September 2018 \\
\hline
\end{tabular}

Keywords:

Onobrychis

Wild

Chromosome

Karyotype

Ideogram

\begin{abstract}
A B S T R A C T
Karyotype properties of of six endemic Onobrychis taxa (O. beata, O. cilicica, O. fallax, $O$. podperae, $O$. sulphurea and $O$. lasistanica) naturally grown in Turkey were determined using squash preparation method and similarity of these endemics with cultivated taxon $(O$. viciifolia) were revealed. Ploidy levels of Onobrychis taxa were diploid $(2 \mathrm{n}=14)$ except $O$. lasistanica and $O$. viciifolia $(2 \mathrm{n}=28)$. Basic chromosome number is $\mathrm{x}=7$ and chromosomes ranged from median to sub median with regard to centromere position. While the longest total chromosome length was measured in $O$. cilicica $(28.21 \mu \mathrm{m})$, the shortest total chromosome length was in $O$. beata $(21.47 \mu \mathrm{m})$. $O$. cilicica and $O$. sulphurea have satellite on chromosome 1 and chromosome 2, respectively. Hierarchical cluster analysis was performed to determine the relationships among the Onobrychis taxa and they were separated into three groups. $O$. fallax, and $O$. podperae were in the first group while $O$. sulphurea and $O$. cilicica were in the second group. $O$. beata, $O$. lasistanica, and $O$. viciifolia were assigned to the third group.
\end{abstract}

\footnotetext{
*Corresponding Author:

E-mail: oileri@ogu.edu.tr

DOI: https://doi.org/10.24925/turjaf.v6i11.1530-1536.1781
}

\section{Introduction}

Sainfoin (Onobrychis viciifolia Scop.) is grown successfully in arid and semi-arid areas. It is cultivated in 196.180 hectares within forage sown in Turkey (TUIK, 2017). Forage quality of sainfoin is very high in terms of crude fat and protein and minerals (Acikgoz, 2001). It is used as a soil improvement plant due to the strong root system and nitrogen fixation characteristics (Acikgoz, 2001; Altin et al., 2005; Elci, 2005).

Wild Onobrychis taxa have an important role in forage breeding program because of high tolerance to biotic and abiotic stress conditions. Onobrychis genus encompasses about 170 taxa around the world and they are spread from the Mediterranean Region to the Zagros Mountains. Turkey is known as an important diversity center includes about 55 taxa and 28 of them are endemic (Hedge, 1970; Aktoklu, 2001; Avci et al., 2014). The studies on wild Onobrychis taxa for morphological, palynological, molecular and cytological contribure the Onobrychis breeding process.

Cytological and cytotaxonomic information of wild Onobrychis taxa are quite useful in determining the phylogenetic relationships of the taxa (Elci and Sancak, 2009). Hejazi and Mahdi (2010) performed a karyological study of 20 taxa (45 populations) of the genus Onobrychis Adans. from different geographic origins and they found the two usual basic chromosome numbers in the genus, $x=7$ abd $x=8$. Sepet et al. (2011) determined chromosome numbers and morphology of eight species of Onobrychis in Turkey and reported the chromosome numbers as $2 n=14,16$ and 28 . Ghanavati et al. (2012) stated that counting ploidy levels in somatic cells in the metaphase of Onobrychis species was difficult. Akcelik Somay et al. (2012) reported that karyotype analysis of the species of Onobrychis was undertaken using squash method and the chromosome numbers of Onobrychis species were determined as $2 n=14$ and $2 n=16$.

In this study, karyologic properties were determined in six endemic taxa (Onobrychis fallax Freyn \& Sint. ex Freyn var. longifolia Aktoklu var. Nov., Onobrychis sulphurea Boiss. \& Bal. var. sulphurea C. Koch Tvzel, Onobrychis podporea Sirj., Onobrychis cilicica Kit Tan \& Sorger, Onobrychis beata Sirj., Onobrychis lasistanica Sirj.) for the first time and one cultivated form (Onobrychis viciifolia Scop.) belong to Onobrychis section and phylogenetic relationship of these taxa were revealed. 


\section{Material and Methods}

Seeds of Onobrychis taxa were collected from natural habitat in Turkey between 2006 - 2009 years within a project (Project no: 1060040) which was supported by Scientific and Technological Research Council of Turkey (TÜBITAK) and these taxa were identified by Prof. Dr. Ahmet Duran (Table 1) and these original seeds were used to observe chromosome characteristics. The images of sepal and petal of these taxa were given in Figure 1. The fruit pods were removed and seeds were kept at $20^{\circ} \mathrm{C}$ until used. These seeds were applied to mechanical scarification with sandpaper for dormancy breaking because of hard or impermeable seed coats before study as described by Avci and Kaya (2013).

Table 1 Names, locations and coordinate informations of Onobrychis taxa

\begin{tabular}{|c|c|c|c|c|c|}
\hline $\mathrm{N}$ & Taxa name & Location & Latitude & Longitude & Height $(\mathrm{m})$ \\
\hline $1 *$ & O. fallax var. longifolia & $\begin{array}{l}\text { Malatya, Arguvan, Çobandere Village, Şotik } \\
\text { Stream Valley }\end{array}$ & $39^{\circ} 00^{\prime} 02^{\prime \prime}$ & $38^{\circ} 12^{\prime} 27^{\prime \prime}$ & 1410 \\
\hline $2 *$ & O. sulphurea var. sulphurea & Kayseri, Hisarcık, Kıranardı oak groove & $38^{\circ} 37^{\prime} 38^{\prime \prime}$ & $35^{\circ} 31^{\prime} 39^{\prime \prime}$ & 1514 \\
\hline $3 *$ & O. cilicica & Mersin, between Mut to Kırobası & $36^{\circ} 41^{\prime} 38^{\prime \prime}$ & $33^{\circ} 37^{\prime} 27^{\prime \prime}$ & 1095 \\
\hline $4 *$ & O. beata & Adana, Karaisali, Koca Çukur Plateau & $37^{\circ} 24^{\prime} 23^{\prime \prime}$ & $35^{\circ} 02^{\prime} 35^{\prime \prime}$ & 1435 \\
\hline $5^{*}$ & O. podperae & Kütahya, Gediz Range & $39^{\circ} 02^{\prime} 22^{\prime \prime}$ & $29^{\circ} 25^{\prime} 42^{\prime \prime}$ & 820 \\
\hline $6^{*}$ & O. lasistanica & Trabzon, Köprübaşı, Kemer Passage & $40^{\circ} 38^{\prime} 00^{\prime \prime}$ & $40^{\circ} 01^{\prime} 00^{\prime \prime}$ & 2426 \\
\hline 7 & O. viciifolia & Kütahya, Gediz, Çavdarhisar & $39^{\circ} 05^{\prime} 53^{\prime \prime}$ & $19^{\circ} 28^{\prime} 51^{\prime \prime}$ & 887 \\
\hline
\end{tabular}

$\mathrm{N}$ : Number, $*$ : shows endemic taxa
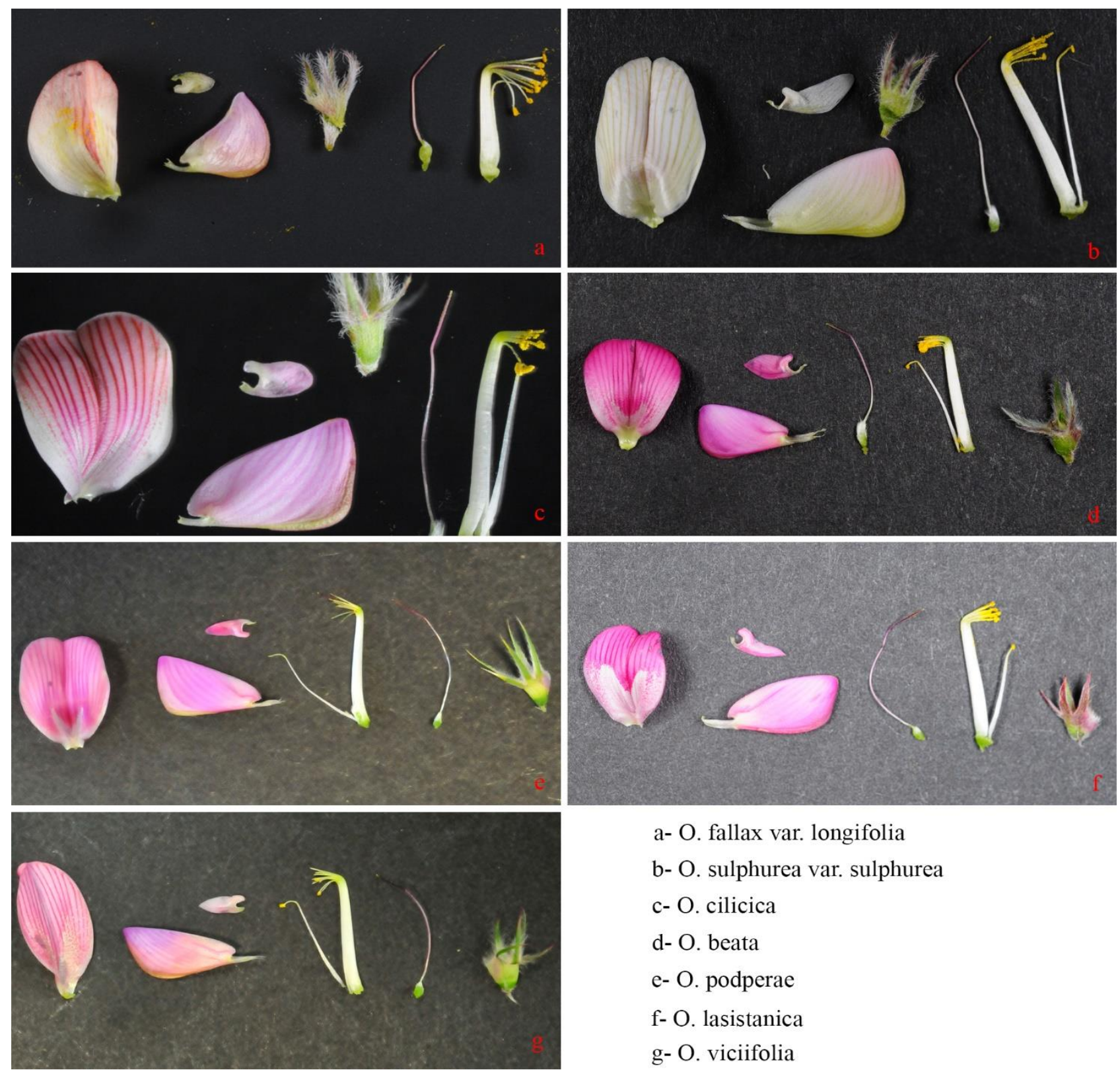

a- O. fallax var. longifolia

b- O. sulphurea var. sulphurea

c- O. cilicica

d- O. beata

e- O. podperae

f- O. lasistanica

g- O. viciifolia

Figure 1 Flower images of investigated Onobrychis taxa indicate sepal, banner petal, wing, keel, stamen and pistil 
The root tips were obtained from germinated seeds at $20^{\circ} \mathrm{C}$ and pre-treatment was performed with $\alpha$ monobromo naphthalene $(0.5 \%)$ for 4 hours at $4{ }^{\circ} \mathrm{C}$. Root tips were subsequently treated with $10 \%$ formaldehyde and 1\% chromic acid (1:1) for 16 hours for fixation and were rinsed with distilled water for 3 hours after fixation (Hejazi and Mahdi, 2010). $1 \mathrm{~N} \mathrm{NaOH}$ solution was used for hydrolysing in $60^{\circ} \mathrm{C}$ between 8 and 12 minutes depending on taxa. Staining was performed with the hematoxylin-iron method and root tips were kept in the dark for 4 hours (Ghanavati, et al., 2012). After staining process, softening treatment was applied with cellulase enzyme (Cellulase from Trichoderma sp., Sigma catalogue no: CO615) for 3 minutes at room temperature due to hardening. Squashing method was used for the preparation of root tips between 1 to $2 \mathrm{~mm}$ lengths by using one drop $45 \%$ acetic acid - lactic acid (10:1) solution. Images that were used in the karyological analysis were captured from 5 different somatic cells using Canon EOS 2000 camera integrated to Zeiss Axio Scope A1 microscope. Chromosome length (CL), short arm length (SA), long arm length (LA), satellite length [(SAT), (if there is satellite)] were measured in Zeiss Axio Vision software. Chromosome length was determined with the sum of short arm length, long arm length and satellite length $(\mathrm{CL}=\mathrm{LA}+\mathrm{SA}+\mathrm{SAT})$. Positions of centromere and chromosome classification were designated with dividing long arm length to short arm length (Levan et al., 1964). Centromere indexes (CI) were derived from dividing short arm length to total chromosome length (TCL) [(CI=SA/TCL $\times 100)]$ as described by Hejazi and Mahdi (2010). Relative length (RL) and arm ratio (AR) values were generated due to the formula given by Akçelik Somay et al. (2012). Ideograms were created by using Microsoft Excel software, Five chromosome characteristics (LA, SA, CI, RL and TCL) were used in generating of dendrogram for each taxon and statistical analysis was performed in SPSS 16 software.

\section{Results and Discussion}

The karyological characteristics and their similarities were revealed in seven Onobrychis taxa, of whose cell images, karyotpe and ideograms were given in Figure 2, Figure 3 and Figure 4 respectively. Cellulase enzyme was used to overcome hard cell walls of Onobrychis taxa during preparation and photography. Ghanavati et al. (2012) confirmed that enzyme treatments on root tips for hard cell walls facilitated the preparation of Onobrychis species. The hydrolysis time to have optimized to obtain good cell staining showed variation among different Onobrychis taxa. The best hydrolysis time was 12 minutes in $O$. cilicica and $O$. lasistanica, 10 minutes in $O$. fallax, O. beata, and $O$. podperae, and 7 minutes in $O$. sulphurea. Yildirim (2007) reported that the hydrolysis time changed according to the species. Sepet et al. (2011) and Akcelik Somay et al. (2012) stated that the hydrolysis time of Onobrychis taxa ranged from 10 to 18 and 7 to 12 minutes, respectively.
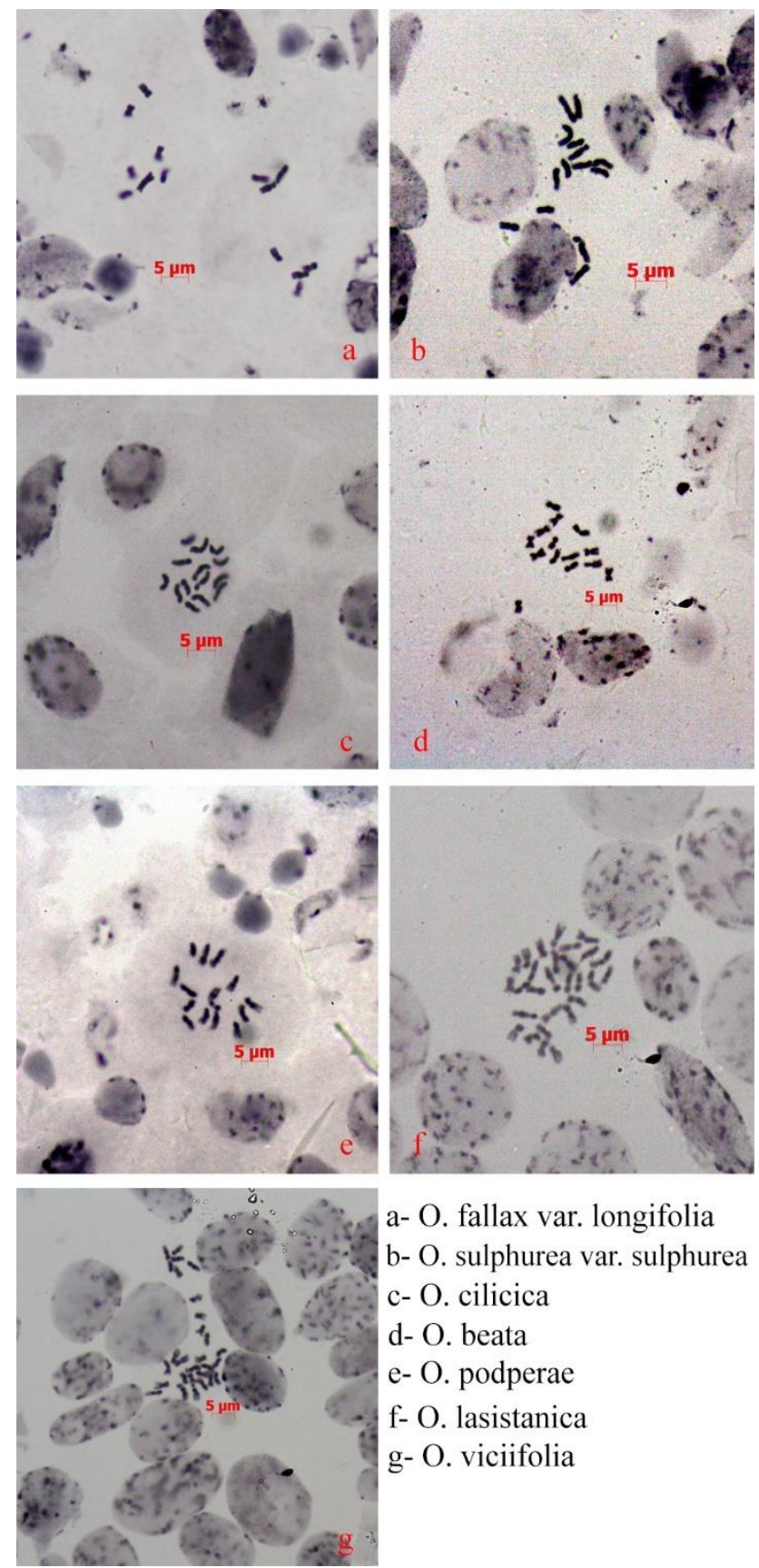

a- O. fallax var. longifolia b- O. sulphurea var. sulphurea c- O. cilicica d- O. beata e- O. podperae f- O. lasistanica g- O. viciifolia

Figure 2. Cell images of investigated Onobrychis taxa in mitotic metaphase stage

Karyological characteristics of all the endemic taxa were determined for the first time, except for $O$. fallax. Basic chromosome number of Onobrychis taxa was $\mathrm{x}=7$ and five of them were diploid $(2 n=14)$, whereas two of them were tetraploid $(2 n=28)$, as illustrated in Table 2 and Figure 2, Figure 3 and Figure 4. In some studies, basic chromosome number of Onobrychis genus was observed to be both $\mathrm{x}=7$ and $\mathrm{x}=8$ (Abou-El-Enain 2002; Hejazi and Mahdi, 2010; Sepet et al., 2011; Akcelik Somay et al., 2012). Ranjbar et al. (2009) and Ghanavati et al. (2012) indicated that Onobrychis genus has different ploidy levels such as $2 \mathrm{n}=2 \mathrm{x}=14,2 \mathrm{n}=2 \mathrm{x}=16,2 \mathrm{n}=4 \mathrm{x}=28$ and $2 n=4 x=32$. 

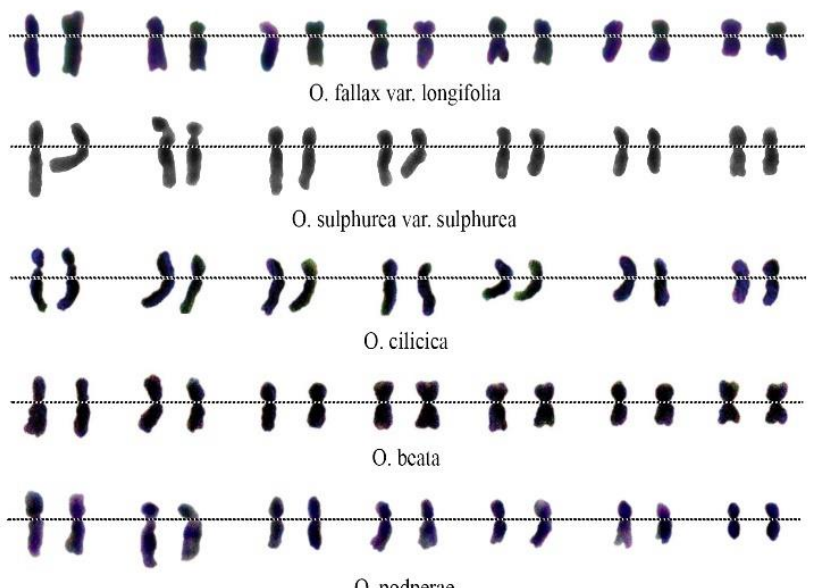

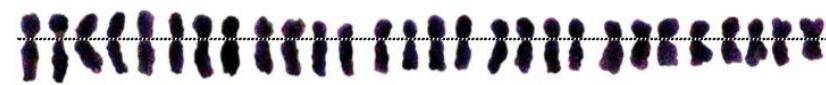

O. lasistanica

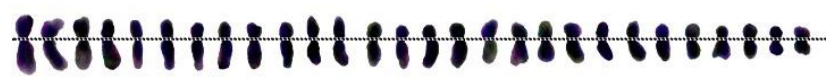

O. viciifolia

Figure 3 Karyotype arrangement of the investigated Onobrychis taxa

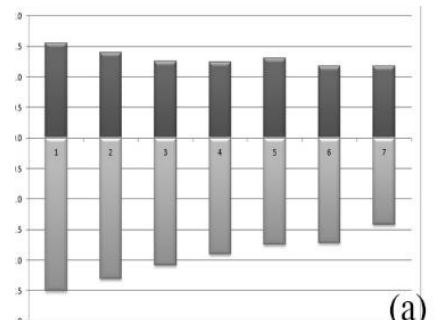

(a)

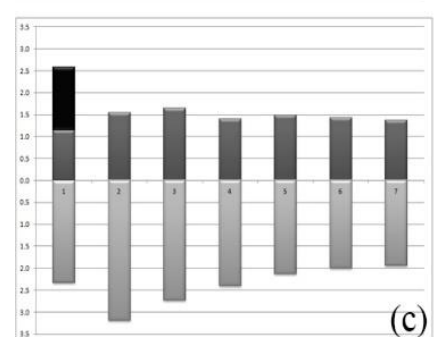

(c)

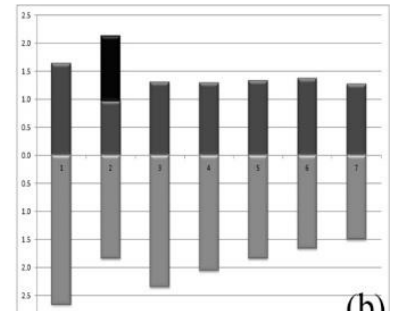

(b)
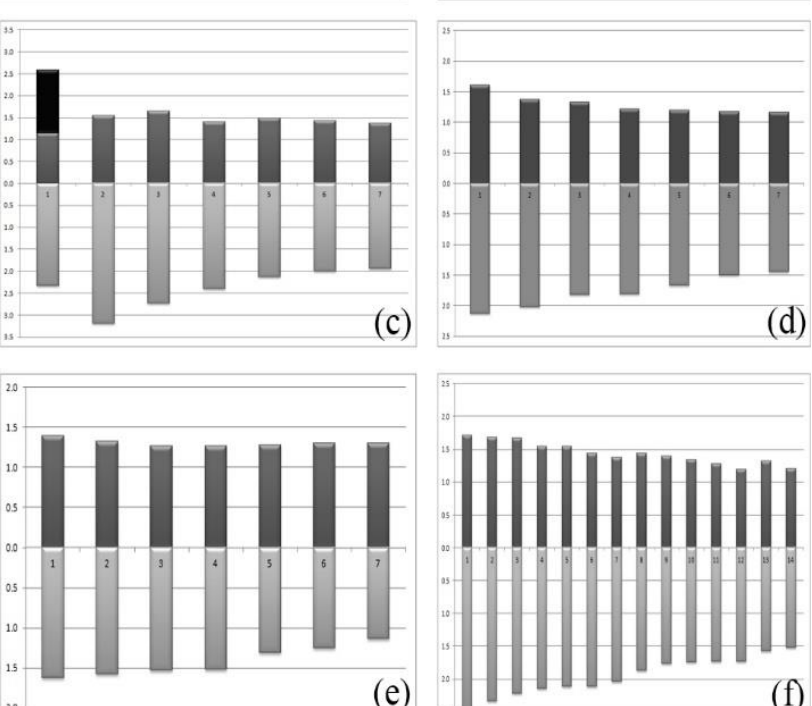

(e)

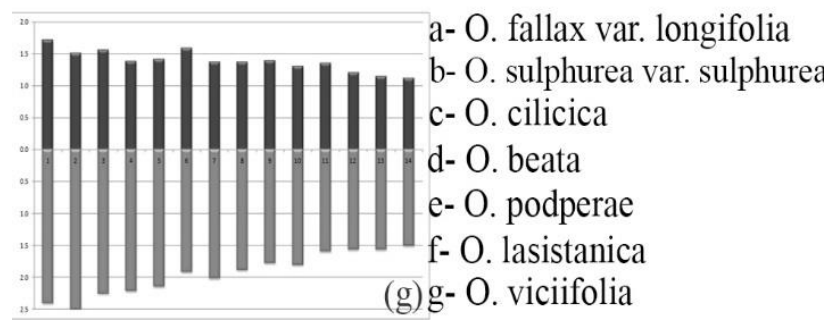

Figure 4 Ideograms of investigated Onobrychis taxa
The total chromosome length varied between 21.47 $\mu \mathrm{m}$ and $28.21 \mu \mathrm{m}$ in $O$. beata and O.cilicica, respectively (Table 2). The chromosome type according to centromeric position ranged from median to sub median as indicated by Hejazi and Mahdi (2010), Sepet et al. (2011) and Akcelik Somay et al. (2012) in certain Onobrychis taxa (Table 3).

O. fallax including two varieties such as fallax and longifolia is an endemic taxon in Turkey. Sepet et al. (2011) reported that $O$. fallax var. fallax showed diploid ploidy level $(2 \mathrm{n}=2 \mathrm{x}=14)$ and median-centromeric chromosomes (m). Our findings of $O$. fallax var. longifolia revealed considerable similarities with the other variety. Karyological properties of $O$. fallax show that these varieties are not conspicuously different from each other.

The $O$. sulphurea taxon is localized to the middle, south, and east of Turkey. There are three different varieties, namely $O$. sulphurea var. vanensis, $O$. sulphurea var. sulphurea, and O. sulphurea var. pallida. The total chromosome length and karyotype formula of $O$. sulphurea var. sulphurea were $24.27 \mu \mathrm{m}$, and $5 \mathrm{~m}+2 \mathrm{sm}$, respectively and this taxon included satellite on chromosome 2 with the length of $1.16 \mu \mathrm{m}$. (Table 2 and Table 3).

The longest total chromosome among the Onobrychis taxa belonged to $O$. cilicica $(28.21 \mu \mathrm{m})$ and centromere position of chromosomes varied from median to submedian, $4 \mathrm{~m}+3 \mathrm{sm}$. Chromosome 1 included a satellite with the length of $1.44 \mu \mathrm{m}$ and the centromeric index ranged from 23.37 to 41.69 (Table 2 and Table 3 ).

$O$. beata, which spreads in a very local area in the southern region of Turkey, had the shortest total chromosome $(21.47 \mu \mathrm{m})$ among the Onobrychis taxa, including only the median chromosome (Table 2). The centromeric index of $O$. beata varied from 40.26 to 44.66 (Table 3).

The total chromosome length of $O$. podperae was $22.64 \mu \mathrm{m}$, and its karyotype formula was $5 \mathrm{~m}+2 \mathrm{sm}$ (Table 2). Centromeric index ranged from 32.73 to 44.90 . Additionally, the arm ratio of $O$. podperae varied from 1.23 to 2.06 (Table 3 ).

$O$. lasistanica and $O$. viciifolia which were similar to each other in terms of chromosome characteristics like ploidy level $(2 n=28)$ and centromere position (median) except other investigated taxa. Also, the total chromosome lengths of $O$. lasistanica and $O$. viciifolia were very close to each other like 23.75 and $23.33 \mu \mathrm{m}$, respectively (Table 2). While the centromeric index of $O$. lasistanica varied from 41.18 to 44.82 , this value ranged from 39.59 to 44.64 in O. viciifolia (Table 3). Hejazi and Mahdi (2010) reported that $O$. viciifolia had tetraploid ploidy level $(2 n=28)$ and chromosomes varied from median to submedian in different populations. Also, we found that centromeric index ranged from 36.00 to 43.00 in this study. However, the presence of satellite showed variability. While some $O$. viciifolia populations included satellite, the others were not as similar to our findings. Our findings showed similarity with the Sepet et al. (2011) who determined the ploidy level of $O$. viciifolia was tetraploid $(2 n=28)$ and its chromosomes were median. 
Table 2 Ploidy level, basic chromosome number, total chromosome length (TCL) and karyotype formula (KF) of the Onobrychis taxa

\begin{tabular}{l|llcc}
\hline \multicolumn{1}{c|}{ Taxa name } & $2 \mathrm{n}$ & $\mathrm{x}$ & TCL $(\mu \mathrm{m})$ & $\mathrm{KF}$ \\
\hline O. fallax var. longifolia & 14 & 7 & 22.78 & $7 \mathrm{~m}$ \\
O. sulphurea var. sulphurea & 14 & 7 & 24.27 & $5 \mathrm{~m}+2 \mathrm{sm}$ \\
O.cilicica & 14 & 7 & 28.21 & $4 \mathrm{~m}+3 \mathrm{sm}$ \\
O.beata & 14 & 7 & 21.47 & $7 \mathrm{~m}$ \\
O.podperae & 14 & 7 & 22.64 & $5 \mathrm{~m}+2 \mathrm{sm}$ \\
O.lasistanica & 28 & 7 & 23.75 & $7 \mathrm{~m}$ \\
O.viciifolia & 28 & 7 & 23.33 & $7 \mathrm{~m}$ \\
\hline
\end{tabular}

Table 3 Chromosome characteristics of the investigated Onobrychis taxa

\begin{tabular}{|c|c|c|c|c|c|c|c|c|}
\hline \multirow{2}{*}{ Taxa Name } & \multirow{2}{*}{ CNTN } & \multicolumn{2}{|c|}{ Chromosome arms $(\mu \mathrm{m})$} & \multirow{2}{*}{$\mathrm{CL}(\mu \mathrm{m})$} & \multirow{2}{*}{ SAT } & \multirow{2}{*}{ AR } & \multirow{2}{*}{ CI } & \multirow{2}{*}{ CT } \\
\hline & & LA & SA & & & & & \\
\hline \multirow{7}{*}{$\begin{array}{l}\text { O. fallax } \\
\text { var. } \\
\text { longifolia }\end{array}$} & I & $2.50 \pm 0.39$ & $1.50 \pm 0.14$ & $4.06 \pm 0.50$ & - & $1.60 \pm 0.17$ & $38.42 \pm 2.65$ & $\mathrm{~m}$ \\
\hline & II & $2.30 \pm 0.20$ & $1.40 \pm 0.28$ & $3.70 \pm 0.40$ & - & $1.64 \pm 0.33$ & $37.84 \pm 4.37$ & $\mathrm{~m}$ \\
\hline & III & $2.09 \pm 0.32$ & $1.26 \pm 0.13$ & $3.35 \pm 0.44$ & - & $1.66 \pm 0.11$ & $37.61 \pm 1.64$ & $\mathrm{~m}$ \\
\hline & IV & $1.90 \pm 0.20$ & $1.24 \pm 0.25$ & $3.14 \pm 0.27$ & - & $1.53 \pm 0.39$ & $39.49 \pm 6.02$ & $\mathrm{~m}$ \\
\hline & $\mathrm{V}$ & $1.74 \pm 0.12$ & $1.30 \pm 0.19$ & $3.04 \pm 0.26$ & - & $1.34 \pm 0.17$ & $42.76 \pm 3.26$ & $\mathrm{~m}$ \\
\hline & VI & $1.72 \pm 0.12$ & $1.17 \pm 0.23$ & $2.89 \pm 0.24$ & - & $1.47 \pm 0.28$ & $40.48 \pm 4.76$ & $\mathrm{~m}$ \\
\hline & VII & $1.42 \pm 0.18$ & $1.18 \pm 0.12$ & $2.60 \pm 0.28$ & - & $1.20 \pm 0.11$ & $45.38 \pm 2.21$ & $\mathrm{~m}$ \\
\hline \multirow{7}{*}{$\begin{array}{l}\text { O. sulphurea } \\
\text { var. } \\
\text { sulphurea }\end{array}$} & I & $2.66 \pm 0.30$ & $1.64 \pm 0.17$ & $4.30 \pm 0.38$ & - & $1.62 \pm 0.22$ & $38.14 \pm 3.25$ & $\mathrm{~m}$ \\
\hline & II & $1.84 \pm 0.18$ & $0.97 \pm 0.08$ & $3.97 \pm 0.22$ & $1.16 \pm 0.24$ & $1.90 \pm 0.26$ & $24.43 \pm 1.63$ & $\mathrm{sm}$ \\
\hline & III & $2.35 \pm 0.26$ & $1.31 \pm 0.25$ & $3.66 \pm 0.25$ & - & $1.79 \pm 0.66$ & $35.79 \pm 6.29$ & $\mathrm{sm}$ \\
\hline & IV & $2.06 \pm 0.35$ & $1.30 \pm 0.12$ & $3.36 \pm 0.35$ & - & $1.58 \pm 0.34$ & $38.69 \pm 5.17$ & $\mathrm{~m}$ \\
\hline & $\mathrm{V}$ & $1.84 \pm 0.19$ & $1.34 \pm 0.20$ & $3.18 \pm 0.30$ & - & $1.37 \pm 0.23$ & $42.14 \pm 3.97$ & $\mathrm{~m}$ \\
\hline & VI & $1.66 \pm 0.13$ & $1.37 \pm 0.14$ & $3.03 \pm 0.22$ & - & $1.21 \pm 0.15$ & $45.21 \pm 2.95$ & $\mathrm{~m}$ \\
\hline & VII & $1.50 \pm 0.17$ & $1.27 \pm 0.13$ & $2.77 \pm 0.30$ & - & $1.18 \pm 0.04$ & $45.85 \pm 0.86$ & $\mathrm{~m}$ \\
\hline \multirow{7}{*}{ O.cilicica } & I & $2.33 \pm 0.32$ & $1.15 \pm 0.25$ & $4.92 \pm 0.56$ & $1.44 \pm 0.18$ & $2.03 \pm 0.31$ & $23.37 \pm 2.50$ & $\mathrm{sm}$ \\
\hline & II & $3.19 \pm 0.64$ & $1.55 \pm 0.31$ & $4.74 \pm 0.47$ & - & $2.06 \pm 1.08$ & $32.70 \pm 7.57$ & $\mathrm{sm}$ \\
\hline & III & $2.74 \pm 0.27$ & $1.65 \pm 0.30$ & $4.39 \pm 0.37$ & - & $1.66 \pm 0.36$ & $37.59 \pm 5.25$ & $\mathrm{~m}$ \\
\hline & IV & $2.40 \pm 0.20$ & $1.40 \pm 0.30$ & $3.80 \pm 0.41$ & - & $1.71 \pm 0.34$ & $36.84 \pm 4.72$ & $\mathrm{sm}$ \\
\hline & $\mathrm{V}$ & $2.13 \pm 0.22$ & $1.49 \pm 0.22$ & $3.62 \pm 0.38$ & - & $1.43 \pm 0.19$ & $41.16 \pm 3.28$ & $\mathrm{~m}$ \\
\hline & VI & $2.00 \pm 0.36$ & $1.43 \pm 0.18$ & $3.43 \pm 0.48$ & - & $1.40 \pm 0.23$ & $41.69 \pm 3.96$ & $\mathrm{~m}$ \\
\hline & VII & $1.94 \pm 0.29$ & $1.37 \pm 0.19$ & $3.31 \pm 0.47$ & - & $1.42 \pm 0.05$ & $41.39 \pm 0.93$ & $\mathrm{~m}$ \\
\hline \multirow{7}{*}{ O.beata } & I & $2.13 \pm 0.39$ & $1.60 \pm 0.09$ & $3.73 \pm 0.41$ & - & $1.33 \pm 0.23$ & $42.90 \pm 3.85$ & $\mathrm{~m}$ \\
\hline & II & $2.02 \pm 0.14$ & $1.37 \pm 0.20$ & $3.39 \pm 0.22$ & - & $1.47 \pm 0.26$ & $40.41 \pm 4.13$ & $\mathrm{~m}$ \\
\hline & III & $1.82 \pm 0.15$ & $1.33 \pm 0.20$ & $3.15 \pm 0.17$ & - & $1.37 \pm 0.35$ & $42.22 \pm 5.14$ & $\mathrm{~m}$ \\
\hline & IV & $1.81 \pm 0.11$ & $1.22 \pm 0.09$ & $3.03 \pm 0.15$ & - & $1.48 \pm 0.14$ & $40.26 \pm 2.33$ & $\mathrm{~m}$ \\
\hline & $\mathrm{V}$ & $1.67 \pm 0.10$ & $1.20 \pm 0.08$ & $2.87 \pm 0.14$ & - & $1.39 \pm 0.11$ & $41.81 \pm 1.88$ & $\mathrm{~m}$ \\
\hline & VI & $1.50 \pm 0.09$ & $1.18 \pm 0.10$ & $2.68 \pm 0.05$ & - & $1.27 \pm 0.18$ & $44.03 \pm 3.51$ & $\mathrm{~m}$ \\
\hline & VII & $1.45 \pm 0.08$ & $1.17 \pm 0.08$ & $2.62 \pm 0.09$ & - & $1.24 \pm 0.13$ & $44.66 \pm 2.59$ & $\mathrm{~m}$ \\
\hline \multirow{7}{*}{ O.podperae } & I & $2.70 \pm 0.17$ & $1.40 \pm 0.30$ & $4.10 \pm 0.38$ & - & $1.93 \pm 0.40$ & $34.15 \pm 4.61$ & $\mathrm{sm}$ \\
\hline & II & $2.59 \pm 0.58$ & $1.26 \pm 0.15$ & $3.85 \pm 0.64$ & - & $2.06 \pm 0.47$ & $32.73 \pm 4.87$ & $\mathrm{sm}$ \\
\hline & III & $2.16 \pm 0.36$ & $1.28 \pm 0.12$ & $3.44 \pm 0.36$ & - & $1.69 \pm 0.36$ & $37.21 \pm 5.38$ & $\mathrm{~m}$ \\
\hline & IV & $1.93 \pm 0.31$ & $1.30 \pm 0.11$ & $3.23 \pm 0.42$ & - & $1.48 \pm 0.13$ & $40.25 \pm 2.12$ & $\mathrm{~m}$ \\
\hline & $\mathrm{V}$ & $1.62 \pm 0.23$ & $1.32 \pm 0.06$ & $2.94 \pm 0.27$ & - & $1.23 \pm 0.16$ & $44.90 \pm 3.36$ & $\mathrm{~m}$ \\
\hline & VI & $1.51 \pm 0.07$ & $1.13 \pm 0.12$ & $2.64 \pm 0.17$ & - & $1.34 \pm 0.12$ & $42.80 \pm 2.22$ & $\mathrm{~m}$ \\
\hline & VII & $1.40 \pm 0.16$ & $1.04 \pm 0.16$ & $2.44 \pm 0.24$ & - & $1.35 \pm 0.23$ & $42.62 \pm 4.21$ & $\mathrm{~m}$ \\
\hline \multirow{7}{*}{ O.lasistanica } & I & $2.41 \pm 0.26$ & $1.69 \pm 0.29$ & $4.11 \pm 0.22$ & - & $1.42 \pm 0.42$ & $41.25 \pm 6.00$ & $\mathrm{~m}$ \\
\hline & II & $2.18 \pm 0.18$ & $1.60 \pm 0.26$ & $3.79 \pm 0.37$ & - & $1.36 \pm 0.18$ & $42.33 \pm 3.45$ & $\mathrm{~m}$ \\
\hline & III & $2.12 \pm 0.31$ & $1.48 \pm 0.21$ & $3.60 \pm 0.47$ & - & $1.43 \pm 0.13$ & $41.18 \pm 2.42$ & $\mathrm{~m}$ \\
\hline & IV & $1.94 \pm 0.20$ & $1.40 \pm 0.26$ & $3.36 \pm 0.40$ & - & $1.39 \pm 0.21$ & $41.84 \pm 3.55$ & $\mathrm{~m}$ \\
\hline & $\mathrm{V}$ & $1.76 \pm 0.33$ & $1.36 \pm 0.19$ & $3.12 \pm 0.38$ & - & $1.29 \pm 0.28$ & $43.68 \pm 4.82$ & $\mathrm{~m}$ \\
\hline & VI & $1.73 \pm 0.40$ & $1.23 \pm 0.17$ & $2.96 \pm 0.37$ & - & $1.40 \pm 0.42$ & $41.63 \pm 6.33$ & $\mathrm{~m}$ \\
\hline & VII & $1.55 \pm 0.30$ & $1.26 \pm 0.07$ & $2.81 \pm 0.30$ & - & $1.23 \pm 0.24$ & $44.82 \pm 4.16$ & $\mathrm{~m}$ \\
\hline \multirow{7}{*}{ O.viciifolia } & I & $2.46 \pm 0.37$ & $1.62 \pm 0.22$ & $4.08 \pm 0.60$ & - & $1.53 \pm 0.13$ & $39.60 \pm 1.97$ & $\mathrm{~m}$ \\
\hline & II & $2.24 \pm 0.23$ & $1.47 \pm 0.25$ & $3.71 \pm 0.46$ & - & $1.53 \pm 0.20$ & $39.59 \pm 2.92$ & $\mathrm{~m}$ \\
\hline & III & $2.04 \pm 0.18$ & $1.50 \pm 0.30$ & $3.54 \pm 0.40$ & - & $1.37 \pm 0.26$ & $42.45 \pm 4.15$ & $\mathrm{~m}$ \\
\hline & IV & $1.96 \pm 0.21$ & $1.37 \pm 0.12$ & $3.33 \pm 0.27$ & - & $1.43 \pm 0.17$ & $41.22 \pm 3.01$ & $\mathrm{~m}$ \\
\hline & $\mathrm{V}$ & $1.80 \pm 0.17$ & $1.35 \pm 0.14$ & $3.14 \pm 0.27$ & - & $1.34 \pm 0.18$ & $42.82 \pm 2.99$ & $\mathrm{~m}$ \\
\hline & VI & $1.59 \pm 0.18$ & $1.28 \pm 0.14$ & $2.87 \pm 0.31$ & - & $1.24 \pm 0.09$ & $44.64 \pm 1.71$ & $\mathrm{~m}$ \\
\hline & VII & $1.54 \pm 0.31$ & $1.14 \pm 0.13$ & $2.68 \pm 0.40$ & - & $1.36 \pm 0.26$ & $42.43 \pm 4.41$ & $\mathrm{~m}$ \\
\hline
\end{tabular}

CNTN: Chromosome number, CT: Chromosome type, \pm : Standart deviation 
Dendrogram for Onobrychis taxa was generated via hierarchical cluster analysis and Onobrychis taxa comprised of three groups (Figure 5). While $O$. fallax var. longifolia, and $O$. podperae were in the first group, $O$. sulphurea and $O$. cilicica were in the second group. $O$. beata, O. lasistanica, and $O$. viciifolia were included as a separate group. Avci et al. (2014) indicated that $O$. beata and $O$. lasistanica were very close together by using SSR markers and they were in the same group with $O$. viciifolia similar to our chromosome findings. In the study about phylogenetic relationship of Onobrychis taxa with the help of morphological and molecular markers by Avci et al. (2016), O. fallax, O. sulphurea and O. podperae included in same group, $O$. beata and $O$. viciifolia were in another group.

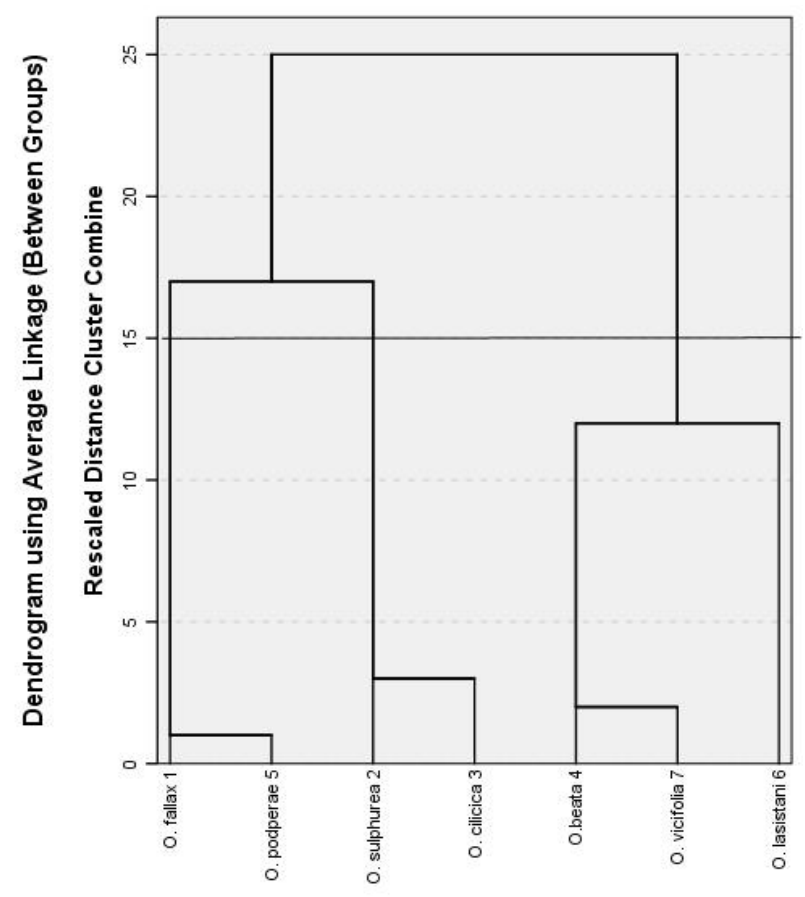

Figure 5 Dendrogram of the investigated Onobrychis taxa created by using five chromosome characteristics (Long and short arm lengths, centromeric index, relative and total chromosome lengths)

\section{Conclusion}

The detailed chromosome characteristics were investigated in six endemic Onobrychis taxa and relation of them to cultivated relative was determined. Karyological properties of six endemic Onobrychis taxa were revealed and there was not any difference with regard to chromosome properties between $O$. fallax var. fallax and $O$. fallax var. longifolia. Basic chromosome number was observed $\mathrm{x}=7$ as expected and ploidy level was generally diploid $(2 \mathrm{n}=14)$ except $O$. viciifolia and $O$. lasistanica $(2 \mathrm{n}=28)$. Chromosomes of Onobrychis taxa are symmetric because of median to submedian in point of centromeric position. Although $O$. fallax var. longifolia and $O$. viciifolia taxa were similar with respect to morphological and molecular markers in some research
(Avci et al., 2014; Avci et al., 2016), they are classified as separate groups in this study. However, our study showed that $O$. lasistanica and $O$. beata are similar to each other and they have high potential to be relative with $O$. viciifolia. This information should be useful in determining taxonomic status of Onobrychis taxa and breeding studies of Onobrychis in the future.

\section{Acknowledgement}

This research was supported by TÜBİTAK (Project number: 106O040) and Eskisehir Osmangazi University (Project No: 201123029). Also, this article was generated from the master's thesis of Onur ILERİ.

\section{References}

Abou-El-Enain MM. 2002. Chromosomal criteria and their phylogenetic implications in the genus Onobrychis Mill. sect. Lophobrychis (Leguminosae), with special reference to Egyptian species. Botanical Journal of the Linnean Society, 139(4): $\quad 409-414$. DOI: $\quad 10.1046 /$ j.1095-8339. 2002.00075.x

Acikgoz E. 2001, Yem Bitkileri, Uludag Universitesi Guclendirme Vakfi Yayin No:182, Yayin No: 58, Bursa, 584 s. ISBN: 975-564-124-6

Akcelik Somay E, Avc1 S, Uzun S, Sancak C. 2012. Karyotype analysis of some Onobrychis (Sainfoin) species in Turkey. Archives of Biological Sciences, 64(2): 567-571. DOI: $10.2298 / \mathrm{ABS} 1202567 \mathrm{~A}$

Aktoklu E. 2001. Two new varieties and a new record in Onobrychis from Turkey. Turkish Journal of Botany, 25(5): 359-363. https://journals.tubitak.gov.tr/botany/ abstract. htm?id $=4973$

Altin M, Gokkus A, Koc A. 2005, Cayır Mera Islahı. T.C. Tarim ve Koyisleri Bakanlıgı Yayınları, Ankara, 468s. ISBN: 975407-188-8

Avci S, Kaya MD. 2013. Seed and germination characteristics of wild Onobrychis taxa in Turkey. Turkish Journal of Agriculture and Forestry 37(5): 550-560. DOI: 10.3906/tar1211-29

Avci S, Sancak C, Can A, Acar A, Pinar NM. 2013. Pollen morphology of the genus Onobrychis (Fabaceae) in Turkey. Turkish Journal of Botany, 37(4): 669-681. DOI: 10.3906/bot-1207-52

Avci S, Ilhan E, Erayman M, Sancak C. 2016. Analysis of Onobrychis Genetic Diversity Using SSR Markers From Related Legume Species. The Journal of Animal and Plant Sciences, 24(2): 556-566. Available from: http:// www.thejaps.org.pk/docs/v-24-2/29.pdf

Avci S, Tekin N, Sancak C, Özcan S, Maraghi AO. 2016. Phylogenetic Relationship of Some Onobrychis Taxa Naturally Grown in Turkey Based on Morphology and Nuclear Ribosomal DNA ITS Sequences. Legume Research, 39(5): 665-673. DOI: 10.18805/lr.v0iOF.11184

Elci S. 2005. Baklagil ve Buğdaygil Yem Bitkileri. T.C. Tarım ve Köyişleri Bakanlığı, Ankara, 486 s. ISBN: 975-407-1896

Elci S, Sancak C. 2009. Sitogenetikte Araştırma Yöntemleri ve Gözlemler. Ziraat Fakültesi Yayınları: 1576, Ankara, 227 s.

Ghanavati F, Nematpajooh N, Khosrow Chahli M, Safaei Chaeikar S. 2012. Cytological evaluation of annual species of the Onobrychis genus in Iran. Crop Breeding Journal 2: 17-24. Available from: http://citeseerx.ist.psu.edu/ viewdoc/download?doi=10.1.1.853.2795\&rep=rep1\&type=pdf

Hedge IC. 1970. Onobrychis Adams. In: Davis, PH (ed.) Flora of Turkey and the East Aegean Islands, Edinburgh University Press, Vol. 3: 560-589. 
Hejazi HSM, Mahdi ZN. 2010. Cytotaxonomy of some Onobrychis (Fabaceae) species and populations in Iran. Caryologia 63: 18-31. DOI: 10.1080/00087114.2010.589705

Levan A, Fredga K, Sandberg AA. 1964. Nomenclature for centromeric position on chromosomes. Hereditas, 52: 201222. DOI: 10.1111/j.1601-5223.1964.tb01953.x

Ranjbar M, Karamian R, Hadadi A. 2009. Biosystematic study of Onobrychis viciifolia Scop. and Onobrychis altissima Grossh. (Fabaceae) in Iran. Iran Journal of Botany, 15: 8595. Available from:
Sepet H, Emre İ, Kıran Y, Kürşat M, Şahin A. 2011. Karyological studies on eight species of Onobrychis genus in Turkey. Biologia 66: 996-1002. DOI: 10.2478/s11756011-0112-4

TUIK 2017. Bitkisel Üretim İstatistikleri, Türkiye İstatistik Kurumu, Ankara.

Yildirim B. 2007. Bazı Lathyrus L. türlerinin karyolojik özellikleri. Ph. D. thesis, Suleyman Demirel University, Isparta. 